\title{
What kind/sort/type of word are these? Number concord across the species noun phrase in International Academic English
}

\author{
ADRIAN STENTON
}

This is a 'postscript' invitation to readers to supply information to the Leiden University 'Bridging the Unbridgeable Project'

Usage guidance on what Biber et al. (1999) call 'species nouns' in English (kind/sort/type +of) has a long history, and has tended to concentrate on number concord between a determiner (e.g. this or these) and kind/sort/type in the singular or plural. Thus we have, from four different centuries:

I ought therefore to say this Sort of Goods sells, and not these Sorts of Goods sell. (Baker, 1770: 115)

I mean the expression 'these' or 'those kind of things.' Of course we all see that this is incorrect and indefensible. We ought to say 'this kind of things,' 'that kind of things.' (Alford, 1864: 69-70)

Those kind. 'Those kind of apples are best': read, 'That kind of apples is best.' It is truly remarkable that many persons who can justly lay claim to the possession of considerable culture use this barbarous combination. (Ayres, 1911: 297)

kind. 'Those are the kind of numbers that easily solve the mystery ...' ' (New York Daily News). Kind and kinds and their antecedents should always enjoy what grammarians call concord. Just as we say 'this hat' but 'those hats', so the writer above should have said, 'Those are the kinds of numbers' or 'This is the kind of number'. Shakespeare, for what it is worth, didn't always observe the distinction. (Bryson, 2002: 111)

More recently, Keizer (2007: Chapter 7) has taken a more nuanced approach to what she calls 'SKT-constructions' (p. 152):
... these constructions can ... be regarded as containing two nominals: a first nominal, $\mathrm{N} 1$, which is always one of three lexical items (sort, kind or type), and a second nominal which belongs to an open class. The two are separated by the element of ... Both N1 and N2 can occur in the singular and the plural; number agreement between the elements is not required. (2007: 152)

One of the purposes of my research, which aims to analyse a self-compiled corpus of International Academic English to see what determines number marking in these constructions, is to investigate whether modern usage guides, many of which claim to make use of corpus data, reflect or refine older usage guidance, as exemplified above. For example, we find:

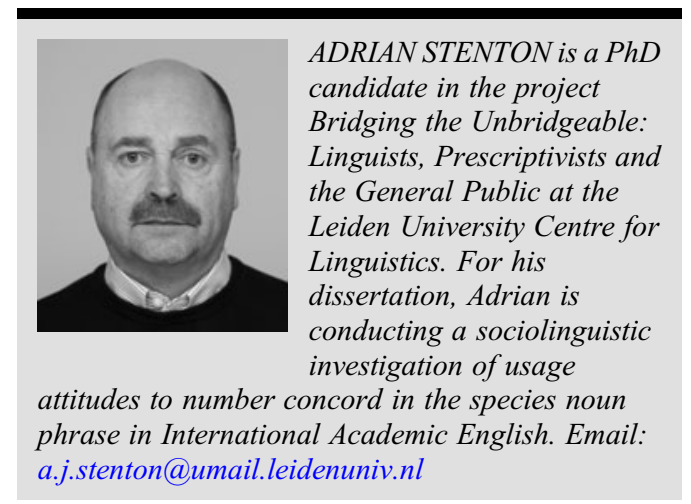


these/those sort of. From the 16c. onwards, sort has been used collectively, preceded (illogically) by these or those ... Not unexpectedly, the plural form these/those sorts of is also used ... The type these/ those sort of should now be used only in informal contexts. (Butterfield, 2015: 763)

*these kind of; *these type of; *these sort of. These illogical forms were not uncommon in the $17^{\text {th }}$ and early $18^{\text {th }}$ centuries, but by the mid- $18^{\text {th }}$ they had been stigmatized. Today they brand the speaker or writer as slovenly. (Garner, 2016: 906)

but also:

sort of. ... [W] hen the phrase is partly or fully pluralized, as in these sort of or these sorts of, it's less clear whether the following noun should be singular or plural. Both constructions are equally well represented in written material from the BNC ... (Peters, 2004: 507-508)

For my research, in addition to analysing what the corpus authors have actually written, I propose to ask them what they think they should write, and to see how this usage reflects established guidance.

This is where, I hope, readers of English Today will become involved as well. I am inviting you to take part in a survey, which I have posted on the Bridging the Unbridgeable blog here: https:// bridgingtheunbridgeable.com/2017/02/14/yet-anothersurvey/. It is a short survey, starting with an example from Mittins et al.'s (1970) Attitudes to English Usage, just to set a bench-mark. This is followed by 12 examples, all taken from my corpus, and differing from Mittins et al. in that they are all presented in context, typically including the sentence before and the sentence following. Apart from teasing out your attitudes to number concord, the survey also gives you the opportunity to comment at length. I am hoping to use your responses to refine the survey for the authors of my corpus.

Thank you in advance for taking part.

\section{References}

Alford, H. 1864. The Queen's English: Stray Notes on Speaking and Spelling. London: Strahan \& Co. and Cambridge: Deighton, Bell, \& Co.

Ayres, A. 1911. The Verbalist: a Manual Devoted to Brief Discussions of the Right and the Wrong Use of Words and to Some Other Matters of Interest to Those who Would Speak and Write with Propriety. New York: D. Appleton and Company.

Baker, R. MDCCLXX [1770]. Remarks on the English Language, in the Nature of Vaugelas's Remarks on the French; Being a Detection of Many Improper Expressions Used in Conversation, and of Many Others to be Found in Authors. To Which is Prefixed a Discourse Addressed to His Majesty. London: n.p.

Biber, D., Johansson, S., Leech, G., Conrad, S. \& Finegan, E. 1999. Longman Grammar of Spoken and Written English. Harlow: Pearson Education.

Bryson, B. 2002. Troublesome Words. London: Penguin.

Butterfield, J. (ed.) 2015. Fowler's Dictionary of Modern English Usage, $4^{\text {th }}$ edn. Oxford: Oxford University Press.

Garner, B. A. 2016. Garner's Modern English Usage, $4^{\text {th }}$ edn. Oxford: Oxford University Press.

Keizer, E. 2007. The English Noun Phrase: the Nature of Linguistic Categorization. Cambridge: Cambridge University Press.

Mittins, W. H., Salu, M., Edminson, M. \& Coyne, S. 1970. Attitudes to English Usage. London: Oxford University Press.

Peters, P. 2004. The Cambridge Guide to English Usage. Cambridge. Cambridge University Press. 